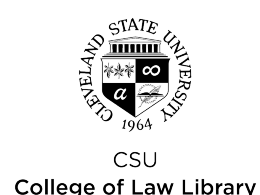

Cleveland State University

College of Law Library

\title{
EngagedScholarship@CSU
}

Spring 2019

\section{Coty, Amazon, and the Future of Vertical Restraints: Evolving Distribution Norms on Both Atlantic Shores}

Chris Sagers

Cleveland-Marshall College of Law, Cleveland State University, c.sagers@csuohio.edu

Follow this and additional works at: https://engagedscholarship.csuohio.edu/fac_articles

Part of the Antitrust and Trade Regulation Commons, and the Consumer Protection Law Commons How does access to this work benefit you? Let us know!

\section{Repository Citation}

Sagers, Chris, "Coty, Amazon, and the Future of Vertical Restraints: Evolving Distribution Norms on Both Atlantic Shores" (2019). Law Faculty Articles and Essays. 988.

https://engagedscholarship.csuohio.edu/fac_articles/988

This Article is brought to you for free and open access by the Faculty Scholarship at EngagedScholarship@CSU. It has been accepted for inclusion in Law Faculty Articles and Essays by an authorized administrator of EngagedScholarship@CSU. For more information, please contact research.services@law.csuohio.edu. 
ESSAY

\section{Coty, Amazon, and the Future of Vertical}

\section{Restraints:}

\section{Evolving Distribution Norms on Both Atlantic Shores}

BY CHRIS SAGERS beyond distribution restraints, because many remember Sylvania as the celebrated turning point after which U.S. antitrust became "economic." 4 Therefore, American lawyers generally understand Coty-type cases as just further problems within the vast esoterica of that latter-day economics literature.

But in thinking about Coty, lawyers won't much bother with its echoes in, say, the 1930s, or the 1880s, or the rest of that benighted time before we discovered the purportedly objective truth, which is to say roughly all of human history before 1977.

In other words, much discussion of this present period of rapidly changing distribution, including discussion of Coty in both America and Europe, is premised on times being meaningfully new when in fact they are not. Many of those who claim that times have changed do so to justify legal flexibility to restrain competition, and in particular to restrain very vigorous retail competitors like Amazon. However, efforts were made throughout the first half of the 20th century to stop very similar innovations, by the adoption of trade restraints, trade organization agitation, and protectionist legislation. Those efforts opposed change that in retrospect seems not to have been so bad. ${ }^{5}$ And so, however new anything might actually be in the present world of online commerce, one thing that seems not so new is producers and distributors trying to stop things that people tried to stop before.

To be clear, no one seriously doubts that the world has changed as a consequence of online distribution, in any number of measurable respects. But whether it has changed in ways relevant to antitrust policy is a different question. On some level, antagonism between producers and their distributors is the oldest story in mass-market capitalism, and the fact that this new period of conflict involves a big technological change is not even factually distinguishing. Some of the first really intense distribution-sector conflicts in America first arose only because rail and telegraph had made mass markets possible. Of course, the mere fact that tension between producers and distributors is the same now as it once was does not prove that nothing needs correction, through private arrangements or government intervention. Even if things haven't really changed, it might just mean that firms really have faced certain market problems, persistently and across different markets. However, the history of similar periods suggests that those seeking legal flexibility now are like those in the past whose efforts now seem problematic.

The Coty decision itself probably means several different things within European law, and it has special technical significance within the EU's intricate vertical restraints rules. It would simplify improperly to claim that Coty was preoccupied solely with the internet, or even with ongoing debates within vertical economics. What is interesting, however, is the general push at present among manufacturers and traditional distributors to protect their interests, which is one reason Coty is worthy of such keen attention on both sides of the Atlantic.
Chris Sagers is James A. Thomas Professor of Law, Cleveland State University. This essay began as remarks at the 2018 Spring Meeting of the ABA Section of Antitrust Law. My thanks for feedback to Melanie Aitken, Steve Cernak, Meg Guerin-Calvert, and Richard Steuer. The arguments here are pursued further in my book, United StATES V. ApPLE: COMPETITION IN AMERICA (forthcoming 2019). 


\section{Context: The Law and Politics of Distribution in Europe and America}

While some policy developments at the moment seem similar in Europe and America, there are also surprising legal differences between the two vertical competition regimes.

As under U.S. law, vertical agreements in the EU have always been subject to Article 101 TFEU, the EU's general law on multilateral trade restraints. ${ }^{6}$ But for that one common fact, however, the two systems diverge pretty far from one another. Generally speaking, the EU law of vertical restraints has been stricter than U.S. law, and as American law has grown more permissive, the divide has grown. The EU's rules most surprise American lawyers not for their strictness, however, but for their elaborate, confusing complexity and their rigorous formalism. A further difference that American lawyers may take a little longer to appreciate- - because it is very subtle and shrouded - is that to some extent the systems serve different purposes.

The EU rules have generated controversy in Europe. ${ }^{7}$ Even following substantial relaxation of the once onerous trade restraints rules generally-by a series of block exemptions starting in the $1980 \mathrm{~s}^{8}$ and then a major decentralization of enforcement in $2003^{9}$ - the EU's substantive law of vertical restraints has remained strict. The EU Commission (EC) has acknowledged criticism and generally endorsed the contemporary economic orthodoxy that vertical restraints are of secondary concern. ${ }^{10}$ One barrier to liberalization, however, has apparently been the CJ's skepticism of the EC's more economic approach, and its determination for now to stick to the formalism of its own case law. ${ }^{11}$

Accordingly, EU law still stands as follows: (a) both minimum resale price maintenance (RPM) and a few special categories of non-price restraints are effectively per se illegal, regardless of any party's market share, and (b) other nonprice vertical restraints are open to challenge if either the upor downstream participant has more than 30 percent of a relevant market. (Where neither party has 30 percent, nonhardcore restraints are presumed legal.) These rules are implemented through block exemption regulations and a set of non-binding EC Guidelines, ${ }^{12}$ and they set out meticulously defined exceptions with which firms must comply to avoid significant legal risk. Agreements must be tailored carefully to these rules, whether they serve the parties' real business goals or not. That problem is known by European critics as the "straightjacket" effect. ${ }^{13}$

This is pretty different from the U.S. regime. During the 1970s, under the influence of a new and much more conservative economics, and a significant change in Supreme Court personnel, ${ }^{14}$ U.S. law began a relaxation that has made vertical restraints very difficult to challenge. Before then the law was comparatively strict. RPM had been mostly per se illegal for more than 50 years; exclusive dealing, tying, and some other non-price vertical restraints were subject to pretty tough rules of their own; and for a brief and controversial period, essentially all vertical restraints were made per se illegal. ${ }^{15}$ But beginning with Sylvania in 1977, and in a series of Supreme Court opinions explicitly invoking the new economic thinking, those tough standards quickly eroded. Though in principle all vertical restraints are still subject to Sherman Act challenge, and the occasional calls to make them per se legal have not been answered, ${ }^{16}$ they have become more or less per se legal as a practical matter. Even RPM is rarely challenged except in Maryland and California, the two states where it remains per se illegal under state law, and even for distribution there, RPM can be made relatively safe with so-called Colgate plans. For some decades, accordingly, EU law has constrained vertical limits quite a bit more than U.S. law, especially since the federal per se rule against RPM was dropped in Leegin Creative Leather Products, Inc. v. PSKS, Inc. ${ }^{17}$

This divergence between the two systems may be driven in part by their somewhat different goals. Most importantly, while EU competition law is just as "economic" as U.S. law, and now mostly explains itself according to consumer-welfare-oriented price theory, it also serves the distinct goal of internal market integration. ${ }^{18}$ Among the specific means by which free trade is meant to strengthen Europe is the spread of opportunity and economic benefits among the member states. Because its members have comparatively small populations, it is thought that those goals are served if they can enjoy scale advantages throughout the internal market, without barriers at their borders. ${ }^{19}$ Accordingly, EU law and its vertical restraints rules in particular are especially concerned with private restraints that would effectively re-establish national trade barriers. ${ }^{20}$ Very strict rules against distribution restraints could make sense given these goals. If manufacturers choose or are pressured to restrict distribution on a country-by-country basis, it could have an effect similar to national trade barriers, and firms in the affected states could lose the scale benefits of freer trade.

For what it may be worth, another theme has had some influence in EU competition law, and it might explain much of the rigor and the resistance to Sylvania-style economic deference to distribution restraints. The law still to some degree seems based on the individual liberty of downstream sellers. ${ }^{21}$ That value has roots in the national laws of some EU member states ${ }^{22}$ and it once explicitly animated U.S. law as well. ${ }^{23}$ It is perfectly "economic" in its faith that better market outcomes follow from the independent decision making of individual businesses. For what it is worth, though, it disfavors restraints that economists now claim to be desirable. ${ }^{24}$

As for the Coty case itself, it might seem surprising that it was watched so closely in Europe. ${ }^{25}$ It was merely the latest decision within an intricate legal framework that governs one specific type of vertical restraint. The European courts had already held that a manufacturer could establish a "selective distribution network" and protect distributors within it from intrabrand competition, but only in certain circumstances. Such a network must meet a set of technical requirements, known as the "Metro criteria," after the cases in which they were devised. Most important in Coty was the Metro 
requirement of proper motivation: "the characteristics of the product in question [must] necessitate such a network in order to preserve its quality and ensure its proper use." ${ }^{26}$ In its earliest Metro cases, the CJ found this requirement met for technological products, which might require skilled instruction or service. Later lower court decisions extended it to "luxury" items. Coty involved one such product, purportedly "luxurious" perfume. The manufacturer prohibited its distributors from reselling over third-party online platforms, like Amazon.

Strictly speaking, Coty was only a preliminary advisory ruling to the national courts of Germany, made under a procedure like the certification of questions by U.S. federal courts to state supreme courts. Moreover, its details are technically intricate, and hard to generalize in any simple summary. But the basic holding in essence was to confirm that luxury is a permissible goal for a selective distribution network, and that it is sometimes permissible to protect it by prohibiting online sales through discernible third-party platforms. In other words, manufacturers can now at least sometimes prohibit European resale of their goods over Amazon.

Within this approach is another striking difference between the U.S. and EU rules. In Europe the legality of a distribution scheme may depend on metaphysical line drawing by judges that seems fairly unguided and subjective. At a minimum, it will produce some odd results. For example, the CJ has now decided that expensive perfume is a "luxury" item that can be properly brand-differentiated with restrictive distribution, but just a few years earlier it held that "cosmetics and body hygiene" products are not. ${ }^{27}$ Odd results seem unavoidable because the lines themselves do not reflect traits inherent in the products. "Luxury" is acknowledged to be an image-driven and ephemeral phenomenon, ${ }^{28}$ and one that is created in part by the very restraints that the product's luxurious nature is said to justify. ${ }^{29}$ That is, restraints are permitted to preserve the luxury image that the restraints themselves create. In fact, essentially any retail product can be differentiated for quality, whether it actually has any quality advantages at all, even if it has perfect substitutes. ${ }^{30}$ Consumers, in other words, can be fooled. So, there is no reason a priori that any particular item is not "luxurious" in this sense.

This approach suggests a deeper difference yet between the two systems. By refusing to entertain such questions, U.S. policy at least in principle leaves them to markets themselves. What products should be sold, and how, seem the kinds of questions that markets usually handle well. The most important paper in the vertical restraints literature, which basically founded the economics on which U.S. law has largely abandoned vertical enforcement, acknowledged as much. Economist Lester Telser observed that, except in special circumstances, consumers will pay to have whatever marketing service or source of information that is desirable to them. ${ }^{31}$ Therefore, if a producer cannot profitably sell a particular kind of product, at a particular quality-adjusted price and with a certain suite of marketing and support services, then
There is a separate reason why Coty seemed so

significant. It is that it involved the internet, and

above all the powerful distributor Amazon, with its

potential to disrupt traditions, settled investments,

ways of doing business, and social values.

that is usually not an argument for limiting retail competition. It is an argument that the product shouldn't be sold in that way or sold at all.

Or at least that is how it should ordinarily be, if Telser's view were taken more seriously. The thrust of his paper was that in some cases, something actually wrong with the market - rather than anything inherent in the nature of the product - might require private restraints to keep price competition from undermining proper distribution. Accordingly, one might have expected U.S. law to require an actual empirical demonstration of free riding or some other plausible reason that a particular market cannot give consumers what they want. In principle it does require some such showing, but as a practical matter, again, that does not actually happen. In practice there just are not any challenges to vertical restraints at all.

The question remains why Coty got so much attention. There are certain technical reasons. For one thing, it reflected the confusion caused by some terse and unexplained language in the 2011 CJ ruling known as Pierre Fabre, which cast doubt on whether protecting brand image could ever justify an anticompetitive restraint. ${ }^{32}$ Coty seems to have resolved that question.

But there is still intense concern over just what Coty means, and what its broader consequences will be for e-commerce. Some think it is narrow, and applies only to some range of "luxury" products with very exclusive brand images. ${ }^{33}$ Some think it is broader, and applies to protection of any branded goods,${ }^{34}$ and some others think it is significant well beyond its own specific technical concerns. If it is, it may render the problem just described - the peculiar metaphysics-academic. It may have already loosened the law going forward so that in every case there will be essentially the same case-by-case treatment concerning whether selective distribution restraints (or platform bans) are permitted, without serious regard to the product's "luxury" or other nature. If it works out that way, then the line of cases culminating in Coty might "suggest that EU law is [now] agnostic about the business model that companies choose." 35

There is a separate reason why Coty seemed so significant. It is that it involved the internet, and above all the powerful distributor Amazon, with its potential to disrupt traditions, settled investments, ways of doing business, and social values. There is accordingly a widely held sense that this new world 
is dangerous, and that legal rules must permit vulnerable parties to protect themselves, for the good of all. As to that, there are some lessons in history.

\section{Lessons from the Past and Thoughts Going Forward}

Online distribution looms ominously in antitrust circles, as one imagines it does in boardrooms and executive suites as well. Queries from manufacturer clients are common on how legally to constrain Amazon, and some lawyers have made niche practices of it. Coty and many other cases in the national and European courts suggest that it is as pressing in Europe as in America

It also poses a policy tension that is really difficult, and that turns out to have a long history. Big changes in distributiona sector that so directly impacts the nature of employment, individual opportunity, and the social fabric of communities - are almost unique in competition history for the confusion and acrimony they cause, and the difficulty of dealing with them through any coherent politics to serve the greater good.

And again, it is key on both Atlantic shores. Consider two big, recent policy initiatives: the so-called "Better Deal" in the United States, a mid-term campaign platform released by Congressional Democrats in 2017, ${ }^{36}$ and the EU's push of the last several years to establish a "Digital Single Market." 37 Those two efforts, seemingly so different in their priorities, goals, and approaches, are actually preoccupied with the same basic problem, and they struggle with it to the same unsatisfactory degree. They stress both the magical-seeming benefits of online distribution and the threat it poses, to settled investment, small business, and social values.

To recognize the conflict is not a criticism. The tension between marketplace vigor and the other social values to which it seems hostile is a problem that no one has really resolved. But it is a problem on which history sheds light. For the dangers that e-commerce and the powerful online platforms pose are not unique or new. They characterize all periods of technological transition, and probably in none so acutely as in transitions in distribution.

The tension can be thought of as two related but distinct problems. On the one hand are the interests of workers, small entrepreneurs, neighborhoods, aesthetic values, and so on, which are jeopardized by the insolvencies and changing business models incident to disruptive change. Those losses are dear and seem genuine, and though they are probably the inevitable incidents of capitalism, they must be addressed in some way by a society that aspires to moral decency and sustainable competition policy. They are not, however, problems likely to be improved by reducing competition in the way implied in calls for better or different vertical restraints. That is treating a real illness with the wrong medicine.

The other problem is how change in distribution affects business firms themselves. Incumbent firms routinely resist change through trade restraints and other defensive measures.
In assessing these firms' arguments that forestalling change to protect them is needed for society, history is a useful guide.

We've Been Here Before. As it happens, Amazon is not the first distributor to generate aggressive logistical improvements, the cost savings of which it translated into vicious, world-changing price competition. It also wasn't Costco, or Walmart, or even the Great Atlantic \& Pacific Tea Company. In the United States such things arose at least as early as the time of the Civil War, when self-service retail shops, multilocation chain stores, and mail order catalog companies first appeared. New distribution models directly threatened older ones, and the settled investment they represented. There followed America's first wide incidence of RPM, and indeed there arose vigorous, nationally organized movements to establish RPM throughout American retail..$^{38}$ The foundations of American vertical relations law were first hammered out during this widespread, long-term struggle. ${ }^{39}$ It later fueled the presidential election of 1912, contributed to the antitrust legislation of $1914,{ }^{40}$ and drove the Robinson-Patman Act, Miller-Tydings laws, and state chain-store taxes. ${ }^{41}$ Newer and lower-cost distribution has always invited attempts to restrain it with private collusion and public policy tools.

\section{Online distribution looms ominously in antitrust}

circles, as one imagines it does in boardrooms

\section{and executive suites as well.}

It is not at all clear that this exercise has been a useful one. For one thing, those policy gestures typically have little longterm effect. And whether they do any particular good, it is pretty clear that they do some harm. Obviously, to the extent that they keep prices high, consumers suffer. But they might also deter allocational efficiency improvements in distribution that are socially critical. As the historian Marc Levinson pointed out in his history of the Great A\&P, before the chain stores, the food to which most Americans had access was high cost and low in variety and quality, and most urban Americans lacked meaningful access to fresh produce. ${ }^{42}$ The politics that led to these distribution policies might strike us now as very strange. For example, people considered it radi$\mathrm{cal}$ and dangerous when stores first allowed consumers to select their own products from shelves. And finally, it seems telling enough that it was consumer advocates who ultimately wanted to end RPM. When a new consumer movement arose in the 1960s and 1970s, it took as one major goal ending the protectionist legislation of the 1930s, like the Miller-Tydings Act, which was repealed in 1975.

As for the other cost of change, the threat to the pecuniary interests of incumbent firms, we can probably be less charitable. Unlike the concerns of workers and communities, it is hard to find any very legitimate defense for distribution restraints based on the pecuniary interests of producers or 
traditional distributors. It really boils down to a struggle between producers and distributors over their share of whatever surplus they can squeeze out of consumers. That struggle is as old as mass-market capitalism. ${ }^{43}$

Given this reasoning, it may seem odd that suppliers should ever disfavor a price-cutting distributor. Other things equal, a manufacturer should want more price competitiveness downstream, not less. The lower the distributor's resale price, the more units will be sold. More units times the manufacturer's per-unit profit should usually mean more profit for the manufacturer. So, one might think that manufacturers who want vertical restraints or some other kind of limitation on a firm like Amazon must have some other, procompetitive reason for wanting it.

But indeed, there is a key reason for a manufacturer to fear aggressive distributors, and it is illustrated very nicely in the history of past periods of change. The cost-cutting distributor usually takes its gains not from consumers, in the form of higher price. Rather, it will most often gain power through expanding market share-which it does through vigorous retail price-cutting, as well as convenience and customer service-in order to exert more power in wholesale price negotiation. That was the story of the Great A\&P, and it appears also to have been the story of Walmart and the warehouse retailers. It appears very emphatically to be the story of Amazon.

If the danger that Amazon poses is just to suppliers' revenues or their currently settled investments, then we should be wary when they claim they must preserve "brand identity" or whatever else through some new vertical restraints. If that really is what is going on in present efforts to preserve brands online, then what people are trying to stop really just seems like something people tried to stop before, for reasons that turned out not to be so wholesome, all to thwart a change that was not ultimately so bad.

Looking Abead. For all those reasons, if Coty represents some progress toward adoption of U.S.-style vertical restraints law, particularly if it is driven by fear of the social disruption of distributional innovation, Europe should proceed with serious caution. On the one hand, the present frustration of producers and incumbent distributors is definitely understandable. Producers want to preserve distribution networks they have built with significant effort and investment, and distributors just want to protect their livelihoods. If vertical restraints are illegal, however, they are left with little recourse. Few producers or distributors at present could stand up to a firm like Amazon unilaterally, and the law would forbid bargaining with it collectively or defending against it through group coercion or boycott. The effort of Apple and several publishers to fix the price of eBooks made that all quite clear, in both America and Europe. ${ }^{44}$ Likewise, at least in America, those seeking a public policy alternative will find themselves in the same position as American newspapers, which presently are in a very uphill struggle for statutory permission to bargain collectively over ad revenues with Google and Facebook. ${ }^{45}$

This just begs a deeper question. While the interests of those pushing for more freedom to restrain distribution in Europe are plain, what they seek is really just to protect the pecuniary interest of quite a limited number of people. It will retard innovation that could help many others, and meanwhile do nothing obviously useful to deal with the larger social threats that a firm like Amazon might actually pose. The American experience should therefore caution against loosening up the law just to solve these problems. In the U.S., the adoption of the underlying theory generated legal changes that proceeded very quickly, and permitted the characterization of any retail-level price competitiveness as potentially dangerous and anti-social. Relatively quickly, there came to be effectively no American law of vertical restraints at all.

An alternative may be to reconceive the "problem" of disruptive change in distribution, which so preoccupies lawyers and regulators in America and Europe, as not a problem at all, or at least not the right problem. Logistical or technological innovation is a highly desirable and perhaps indispensable good. If it generates genuine human losses-as opposed to mere change in individual firms' leverage in wholesale price negotiations - they should be met with policy tools that actually treat them. They should not be addressed by reductions in competition, which will not fix them and will just cause other problems. And to whatever extent Amazon in fact causes anticompetitive harms, that too is a call for more competition, not less. It may very well be that Amazon has done more than just price aggressively. But if it has engaged in exclusionary abuses to get its big market shares, the right response is monopolization challenge, not restraints to protect its distributor competitors.

\footnotetext{
1 Case C-230/16, Coty Germany GmbH v. Parfümerie Akzente GmbH, ECLI:EU:C:2017:941 (CJ Dec. 6, 2017) (Coty).

2 See, e.g., Katarzyna Czapracka, The Transatlantic Divide on Verticals-The Underlying Reasons and the Way Forward, 62 ANTITRUSt BULL. 294 (2017); Pablo Ibañez Colomo, Case C-230/16, Coty Germany GmbH: Common Sense Prevails (Dec. 6, 2017), https://chillingcompetition.com/?s= Pablo+coty; Valentine Korah, From Legal Form Toward Economic EfficiencyArticle 85(1) of the EEC Treaty in Contrast to U.S. Antitrust, 35 ANTITRUST BuLL. 1009, 1021-22 (1990).

3433 U.S. 36 (1977).
}

\footnotetext{
4 See, e.g., United States v. Anthem, Inc., 855 F.3d 345, 376 (D.C. Cir. 2017) (Kavanaugh, J., dissenting); Robert H. Bork, The Antitrust Paradox: A Policy at War With ItSelf 430 (1978).

5 See generally Ellis Hawley, The New Deal and the Problem of Monopoly (1966); Marc Levinson, The Great A\&P and the Struggle for Small Business in America (2011); Joseph Cornwall Palamountain, The Politics of Distribution (1955); Basil S. Yamey, The Origins of Resale Price Maintenance: A Study of Three Branches of Retail Trade, 62 Econ. J. 522 (1952).
} 
6 Consolidated Version of the Treaty on the Functioning of the European Union, art. 101, 2012 O.J. (C 326) 47 [hereinafter TFEU]. See Spencer Weber Waller, Understanding and Appreciating EC Competition Law, 61 ANTITRUSt L.J. 55, 55-56, 62 (1992) (providing an overview of Articles 101 and 102 TFEU, which roughly correspond to Sherman Act Sections 1 and 2).

7 See, e.g., Opinion of Advocate General Wahl, C-230/16, Coty Germany, GmbH v. Parfümerie Akzente, GmbH, ECLI:EU:C:2017:603, I 8 (July 26, 2017) (noting that "the legislation and the case-law relating to vertical agreements have been the subject of a veritable "Fronde," or civil war, among European academics).

8 See generally Einer Elhauge \& Damien Geradin, Global Antitrust Law and Economics (2d ed. 2011).

9 Council Regulation No. 17/62, 1959-1962 O.J. Spec. Ed. 87, centralized enforcement in the Commission, at the Commission's request, so the Commission could generate coherent law in the regime's early life. See Korah, supra note 2, at 1015 \& n.12. Enforcement was decentralized by subsequent Council Regulation in 2003. Council Regulation (EC) No. $1 / 2003$ on the Implementation of the Rules on Competition Laid Down in Articles 81 and 82 of the Treaty, 2003 O.J. (L 001) 1.

10 Eur. Comm'n, Guidelines on Vertical Restraints, 2010 O.J. (C 130) 98; A.C. Witt, Restrictions on the Use of Third-Party Platforms in Selective Distribution Agreements for Luxury Goods, 12 Eur. Comp. J. 435, 441-42 (2016).

11 See generally Czapracka, supra note 2; Romano Subiotto \& Filippo Amato, The Reform of the European Competition Policy Concerning Vertical Restraints, 69 Antitrust L.J. 147 (2001).

12 Guidelines on Vertical Restraints, supra note 10.

13 See, e.g., Czapracka, supra, note 2, at 306-08.

14 See Chris Sagers, \#LOLNothingMatters, 63 Antitrust Bull. 7, 20-21 (2018).

15 See United States v. Arnold, Schwinn \& Co., 388 U.S. 365 (1967).

16 See, e.g., Alan J. Meese, Intrabrand Restraints and the Theory of the Firm, 83 N.C. L. Rev. 5 (2004); Richard A. Posner, The Next Step in the Antitrust Treatment of Restricted Distribution: Per Se Legality, 48 U. CHI. L. REV. 6 (1981).

17551 U.S. 877 (2007).

18 See e.g., Czapracka, supra note 2, Korah, supra note 2.

19 Korah, supra note 2, at 1010-11.

20 Waller, supra note 6 , at 66-68.

21 See Witt, supra note 10 , at 458.

22 Korah, supra note 2, at 1015 n.13.

23 See, e.g., Dr. Miles Med. Co. v. John D. Park \& Sons Co., 220 U.S. 373, 406-08 (1911), overruled by Leegin Creative Leather Prods., Inc. v. PSKS, Inc., 551 U.S. 877 (2007); United States v. Colgate \& Co., 250 U.S. 300, 307 (1919).

24 For criticism on these and other points, see Czapracka, supra note 2; Korah, supra note 2, at 1020-21; Opinion of Advocate General Wahl, supra note 7 , at 8 .

25 See, e.g., Ariel Ezrahi, The Ripple Effect of Online Marketplace Bans, 40 World Competition 47 (2017); Ibañez Colomo, supra note 2; Witt, supra note 10 , at 449 .

26 The original cases were Case 26/76, Metro SB-Großmärkte GmbH \& Co. KG v. Commission of the European Communities, 1977 E.C.R. 1875 (Metro I), and Case 75/84, Metro SB-Großmärkte GmbH \& Co. KG v. Comm'n, 1986 E.C.R. 3021 (Metro II). The Metro rules are now codified in Commission Regulation No. 330/2010 on the Application of Article 101(3) of the Treaty on the Functioning of the European Union to Categories of Vertical Agreements and Concerted Practices, 2010 O.J. (L 102) 1 [hereinafter Regulation 330/2010].

27 Case C-439/09, Pierre Fabre Dermo-Cosmétique v. Président de l'Authorité de la Concurrence and Ministre de l'Économie, de l'Industrie et de l'Emploi, 2011 E.C.R. I-09419, ๆ 46 (Pierre Fabre).
28 Coty, ECLI:EU:C:2017:941, ๆ 25.

29 Id. ๆๆ 26-27 (“[T]he characteristics and conditions of a selective distribution system may, in themselves, preserve the quality and ensure the proper use of such goods .... [A] system which seeks to ensure that the goods are displayed in sales outlets in a manner that enhances their value contributes to the reputation of the goods at issue and therefore contributes to sustaining the aura of luxury surrounding them").

30 See, e.g., FTC v. Procter \& Gamble Co., 386 U.S. 568, 572 (1967) (noting that Clorox had successfully differentiated liquid bleach, even though all bleach is chemically identical).

31 Lester G. Telser, Why Should Manufacturers Want Free Trade?, 3 J.L. \& Econ. 86, 89 \& n.4 (1960).

32 Pierre Fabre, 2011 E.C.R. I-09419, ๆ 46. To understand the confusion caused by Pierre Fabre before its clarification in Coty, see generally Witt, supra note 10 .

33 See, e.g., Stephen Kinsella \& Pola Karolczyk, The Coty Debate: Can the Luxury Sector Re-Fragment the Democratic Web?, ANTITRUst, Summer, 2018, at 88.

34 See, e.g., Eur. Comm'n, Competition Policy Brief: EU Competition Rules and Marketplace Bans: Where Do We Stand After the Coty Judgment? (Apr. 2018), http://ec.europa.eu/competition/publications/cpb/2018/kdak 18001enn.pdf.

35 Ibañez Colomo, supra note 2.

36 See http://www.democraticleader.gov/abetterdeal/. Specific antitrust proposals appear in https://www.democraticleader.gov/wp-content/uploads/ 2017/07/A-Better-Deal-on-Competition-and-Costs.pdf.

37 See generally Eur. Comm'n, Communication from the Commission to the European Parliament, the Council, the European Economic and Social Committee and the Committee of the Regions on the Mid-Term Review on the Implementation of the Digital Single Market Strategy, COM(2017) 228 (Oct. 5, 2017); Eur. Comm'n, Staff Working Document: A Digital Single Market Strategy for Europe-Analysis and Evidence Accompanying the Document Communication from the Commission to the European Parliament, the Council, the European Economic and Social Committee and the Committee of the Regions, a Digital Single Market Strategy for Europe, SWD (2015) 100 (June 5, 2015); Katri Havu, The EU Digital Single Market From a Consumer Standpoint: How Do Promises Meet Means?, 9 Contemp. Readings IN L. \& Soc. Just. 146 (2017).

38 See Rudolph J.R. Peritz, "Nervine" and Knavery: The Life and Times of Dr. Miles Medical Company, in Antitrust Stories 61, 64-65 (Eleanor M. Fox \& Daniel A. Crane, eds. 2007).

39 Straus v. Victor Talking Mach. Co., 243 U.S. 490 (1917); Strauss v. Am. Publishers Ass'n, 231 U.S. 222 (1913); Dr. Miles, 220 U.S. 373; BobbsMerrill Co. v. Strauss, 210 U.S. 339 (1908); Straus v. Am. Publishers Ass'n, 177 N.Y. 473 (N.Y. Ct. Apps. 1904); Straus v. Notaseme Hosiery Co., 240 U.S. 179 (1916); Hatfield v. Straus, 82 N.E. 172 (N.Y. 1907).

40 See generally Martin J. SkLar, The Corporate Reconstruction of American Capitalism, 1890-1916: The Market, the LaW, and Politics (1988).

41 See generally HAWLEY, supra note 5.

42 LEVINSON, supra note 5.

43 See generally Herbert Hovenkamp, Mergers and Buyers, 77 VA. L. REV. 1369, 1370 (1991); Robert L. Steiner, The Evolution and Applications of Dual-Stage Thinking, 49 ANTITRust BulL. 877 (2004); Robert L. Steiner, The Prejudice Against Marketing, J. MARKeting, July 1976, at 2.

44 United States v. Apple, Inc., 791 F.3d 290 (2d Cir. 2015); Case COMP/ 39.847, E-BOOKS, Comm'n Decision, 2013 O.J. (C 378) 1 (Dec. 12, 2012) (summary). See generally SAGERS, supra note 14.

45 See David Chavern, How Antitrust Undermines Press Freedom, WALL ST. J., July 10, 2017, at A17. 